\title{
The reconstruction of physical education teachers: A critical discourse analysis of regulative texts
}

\author{
Lise Porsanger \\ Norwegian University of Science and Technology
}

\begin{abstract}
In 2008, the Norwegian Directorate for Education and Training implemented a new circular with directives for water activities in schools and with a call for testing teachers' water competence. This circular seems to align with international school safety policies, where additional regulations and safety guidelines are put into practice in school programs such as physical education. Despite this, studies that have applied a critical discourse perspective on regulative texts in physical education seem scarce. The purpose of this article is to examine how teachers' risk and safety management in physical education is constructed in five regulative documents governing primary and secondary schools in Norway. Norman Fairclough's critical discourse methodology has been applied to conduct a linguistic and contextual analysis of language. The analysis seems to reveal a discourse that challenge teachers' autonomy and position. Because the discourse can appear to be neutral and imperative, it might be taken for granted in the field. The entrancement of a controller in examining teachers' water competence seems to reflect ideals of revision and central control. This article therefore contributes to the understanding of regulative discourses and their power, in education and physical education.
\end{abstract}

Keywords: School; risk; profession; ideology; power

Received: January, 2020; Accepted: May 2020; Published: June, 2020

\section{Introduction}

Schools and teachers have a special obligation and mandate to prevent injuries and harm to students but sometimes fail. There are signs of an established practice of enforcing increased regulation following accidents, injuries, and deaths of students in schools. However, there might be good reasons for their implementation, because inadequate risk assessment has been related to the death of students in Australia, for example (Dallat, Salmon, \& Goode, 2015). A current range of new requirements has

^Correspondence: Lise Porsanger, epost: lise.porsanger@ntnu.no

(C) 2020 L. Porsanger. This is an Open Access article distributed under the terms of the Creative Commons Attribution 4.0 International License (https://creativecommons.org/licenses/by-nc/4.0/), allowing third parties to copy and redistribute the material in any medium or format and to remix, transform, and build upon the material for any purpose, even commercially, provided the original work is properly cited and states its license. 
subsequently been launched, such as student-teacher ratios and additional teacher qualifications (Barwood, 2018). In England, the drowning deaths of four schoolchildren in 1993, enforced new regulations and safety guidelines on school trips (Ball-King, Watt, \& Ball, 2013). The Association for Physical Education (2016) in the UK also promotes common procedures in physical education (PE) to "protect students and [teachers] from potential risks".

In Norway on the other hand, students' safety in PE, has largely remained unaffected by the regulative practice found in the UK and Australia. Thus, teachers have had considerable discretionary space. However, the entrance of a detailed circular addressing water activities in schools seems to incur changes to policy in Norway as well (Norwegian Directorate for Education and Training [Udir], 2015a). This circular is the only official instruction on how to conduct a physical activity in PE, including a call to test teachers' competence.

On that note, the Norwegian Directorate of Health (2019, p. 14) found that 4,3 percent of the reported injuries in 2018, occurred from participation in physical activities and exercise in education. However, one out of what seems to be a scarcity of studies of physical injuries in Norwegian schools, found that 0,6 percent of the registered cases in years 1995-1997, were related to swimming (Schullar \& Kopjar, 2000). In contrast, 14,2 percent were related to gymnastics. The same study failed to find any measures with documented preventive effects on injuries in schools. In addition, there does not seem to be any current official report on student injuries related to PE, or statistics that connect drownings to schooling in Norway. Clearly, there are some dilemmas that rise in this landscape.

First, albeit it is possible that Udir has available non-official data, it seems uncertain why directions were imposed on water activities, thus, excluding all other physical activities. Moreover, why an annual test of teachers' water competence is called for, remains unanswered. All things considered, a rationale in ensuring students' safety might seem obvious. However, this article aims to put a critical light on that idea. It is specifically what seems to be ambiguous grounds for implementing the circular, and the "problem" it is set to solve, that emphasize a need for critical investigations.

With that background, studies that have critically examined regulative texts in terms of risk and safety management (RSM) in PE, seems scarce. This article will therefore examine five selected regulative documents targeting teachers' RSM in PE in Norway. Thus, this article conforms to a critical agenda, to reveal hidden power in the regulative policy change, through an examination of the texts (Fairclough, 1992, 2013). The aim is operationalized in the following research question:

How are teachers' risk and safety management in physical education constructed in regulative documents?

The remainder of the article is organized as follows. First, the theoretical underpinnings to position the texts, explain teachers' contexts and the social systems within which they act and operate will be presented. Thereafter, the article's methodology 


\section{Porsanger}

will be outlined, followed by an analysis and a discussion of the findings in dialogue with social theory. Finally, concluding remarks will be made.

\section{Physical education and RSM}

$\mathrm{PE}$ in Norway is a mandatory curricular program in primary and secondary education. A national curriculum for PE, promotes various experience and physical activities such as outdoor education and swimming, through a range of competence aims (Udir, 2015b). Thus, due to risk of physical injury, it is fair to claim that managing students' safety is within PE teachers professional mandate. However, from a constructionist perspective, what is perceived as risk as well as the social and cultural acceptance, changes with time (Russell \& Babrow, 2011). Today, risk is a central organizing and meaning-making component with special contemporary importance, and some even claim that society has been colonized by the idea (Rothstein, Huber, \& Gaskell, 2006). Through processes of juridification, social problems are increasingly being perceived as legal problems (Magnussen \& Nilssen, 2013). Thus, risk discourses seem to have created a demand for, and use of, regulatory frameworks and controls to ensure students' safety. As a result, the regulative system and logic has an increasingly dominant position within institutions (NOU 2003:19; Power, 1997, 2004).

The heightened concern for risk also seems to center around the question of "[h]ow safe is safe enough?" (Fischhoff, Slovic, Lichtenstein, Read, \& Combs, 1978, p. 1). Safety norms and what is defined as the appropriate state of students' safety (Maurice et al., 2001), will influence how this is dealt with in education (Aven \& van Kessenich, 2019). The Courts of Law also construct standards for teachers' duty of care and negligence in PE (Murphy \& Beh, 2014; Sawyer, 2011a). Thus, "[t]he idea of risk is bound up with the aspiration to control [...] the future" (Giddens, 1999, p. 3) and institutionalized in risk management (Rothstein, 2006).

The attempts to identify, assess, manage and communicate risk and safety, is in this article framed as RSM. The government and Udir are positioned to define hegemonic discourses in the field because they are responsible for governing compulsory education in Norway. Thus, regulative policy texts, such as acts, regulations and circulars will be used to coordinate and communicate their RSM policy (Schmidt, 2008). Noteworthy, the promotion of RSM has also been connected to neoliberal discourses aiming to control teachers and is not necessarily interpreted as a neutral practice (Evans, 2014, p. 549). This is an interesting perspective to the many discussions of mandatory standards and safety guidelines in PE (Benes, 2013; Rothe, 2009; Sawyer, 2011 b; Severs, Whitlam, \& Woodhouse, 2003).

However, it is not possible to predict how teachers translate regulative RSM policy into their PE practice. Clearly, policy texts are 'contested, interpreted and enacted' by teachers in different ways (Ball, 2017, p. 10). As an example of how they may solve RSM in Norwegian context, outdoor education teachers' safety strategies in upper 
secondary education incorporate both inclusion and exclusion of students to deal with risk in their program (Dahl, Standal, \& Moe, 2018). Looking internationally, some claim that teachers in the UK fear bringing students on excursions (Rothstein, 2006), while others claim that this fear is exaggerated (Health and Safety Executive, 2011). In Korea, some PE teachers have developed a safety-first policy; they are hesitant to teach activities that entail risk of harm, as liability has become their primary concern (Park, 2018). In Canada, excluding certain activities from the PE program seems to be a legitimate strategy among teachers to avoid risk and injuries (Young, 2007). The teachers nevertheless did not report fear of litigation as decisive for their practices, but moreso reported their general concern for students' safety. As a possible result of contesting discourses, Forest School teachers in the UK have reported tension between their pedagogy and cultural and institutionalized risk aversion (Connolly \& Haughton, 2015). How Norwegian PE teachers solve this problem on the other hand, remains unanswered.

\section{Theoretical foundation}

The regulative system and the teacher profession

To discuss the relationship between regulation of PE and teachers in this specific context, the article views teachers as a profession (Abbott, 1988; Freidson, 2001). As a profession, they are expected to manage their tasks through special training and knowledge. Teachers have traditionally enjoyed autonomy and the use of discretion is presented as a key to solve their missions. The need for discretion is therefore connected to their status within the field and in their professional knowledge (Boote, 2006, p. 462; Freidson, 2001, p. 35). Therefore, it seems sensible that PE teachers practice and keep up to date on their professional knowledge. This applies to all physical activities in PE and especially those constructed to be of greater risk of physical injury. Clearly, to claim jurisdiction for ensuring students' safety in PE, it must be legitimized through the need for discretion, provided with the necessary trust from relevant stakeholders (Abbott, 1988, p. 40). Trust is an essential component for teachers' autonomy, whereas lack of trust would promote increased external regulation (Molander, Grimen, \& Eriksen, 2012). Dworkin's (1978, p. 31) doughnut metaphor is applied to create dialogue between regulation and professional discretion in this article. It will be used to illustrate how a doughnut belt of regulation restricts and controls teachers' discretional space symbolized by open area of the doughnut. Some have described similar practices in terms of external accountability (Molander, Grimen, \& Eriksen, 2012).

Dworkin (1978) further separates between weak and strong discretion regarding teachers' perceptions of discretional space. When teachers have a strong sense of discretion, they are not bound by any standards or authority in their considerations and are permitted to use discretion more freely. This is an argument with limitations, however, because discretional space also depends on whether principles and recommended 


\section{Porsanger}

standards are given the power of rules in the field, such as recommendations in the circular, even when they are not sanctioned by law (Dworkin, 1978, p. 35). Legal texts such as the Norwegian Education Act (1998) however, often require interpretation, and when teachers experience strong discretion, they construct measures based on their professional knowledge. In contrast, a dismissal or devaluation of discretion to manage risk and safety, might promote weak discretion: where teachers feel obliged to select between predefined measures. The belt may play an increasingly important role in governing teachers' RSM in PE due to the practice of implementing additional regulations and standards of practice. As a result, teachers might become amenable to, for example, safety guidelines, standards or recommendations.

\section{Discourse, language, and power}

To analyze language in the texts, the article draws on Fairclough's $(1992,2013)$ critical discourse methodology. Discourses are viewed as social constructions that are created by social structures but also create them in return (Fairclough, 2013, p. 59). In other words, discourses in the texts will seek to both shape and reflect ideas of RSM. This article will therefore seek to provide insight into how RSM is constructed in selected regulative documents.

By creating a dialogue between Fairclough's approach to language and Bourdieu's $(1990,1995)$ theory of power and dominance in social fields, the article has tools to analyze power relationships and ideologies in the texts with reference to their social context. The texts are promoted from a position with power, and the government and Udir as key regulating actors, "get[] this authority not from a merely factual power of sanctions, but from a power of sanctions recognized as legitimate by citizens" (Habermas, 1987, p. 177). Albeit use of power in itself may be criticized, it might also be necessary. Thus, the reduction of teachers' autonomy and discretional space might be legitimate if they are not taking care of students' safety. However, by viewing the texts as powerful meaning makers, the article will seek to disclose how those in power use language to promote their ideology and reduce alternatives. Thus, it is not power per se, but the ideology hidden in the texts and what consequences that may have, and how it may influence relationships between actors, that is investigated (Skrede, 2017 , p. 29). How the regulative texts construct teachers' RSM may contribute to the understanding of how teachers are positioned and how the texts promote and construct power between actors in the field.

Central in this aspect is that dominant discourses and ideas might come forward as neutral (Bourdieu, 1990, 1995). Noteworthy, when the ideology in a text is least visible, it is the most powerful (Fairclough, 2013). Thus, because texts always incorporate a certain ideology, regulative texts that govern PE make teachers accountable to what might be hidden to them. Therefore, dominant ideas and discourses in the texts will be investigated through the concept of doxa representing convictions that seem 'common sense' and natural in the field (Bourdieu, 1995). By examining what is stated, and especially what is unformulated, it is possible to suggest what might 
be taken for granted. Thus, doxa contributes to reproduce power relationships and ideology because it might seem unquestionable. Teachers' with a heterodox position, on the other hand, would not share those convictions or find the dominant RSM discourse to be natural in PE. Hence, they might make use of other approaches to RSM and develop alternative discourses.

Although it is not possible to draw a clear line between policy and practice, their construction of RSM has the potential to contribute, change, or uphold dominant power relationships as well as teachers' convictions and practices (Bourdieu, 1995). It is in the meeting between the structures and processes these texts represent, and teachers' agency, that RSM practices in PE are made. Therefore, it is central to deconstruct the texts to open up the ideology that are set to control teachers. It is then, when teachers are aware and may question the dominant discourse, it would be necessary for the governing actor to explicitly state the purpose. Thus, in creating a discursive democracy, where hegemonic discourses are challenged, students' safety might be ensured on open premises. The critical discourse analysis (CDA) therefore becomes a political tool to promote democracy in education (Dewey, 2008; Taylor, 2004).

\section{Material and methods}

The study is designed as a qualitative document analysis (Bowen, 2009), in which Fairclough's $(1992,2013)$ CDA is the applied method. CDA is both a method to treat data and a theoretical approach, which is why Fairclough (2013, p. 234) describes the approach as a methodology. This entails combining a linguistic and a contextual analysis of semiosis. In other words, the documents and texts are considered as elements within a larger system that stand in relation to and contribute to each other. According to Fairclough (2013, p. 132), the CDA model incorporates three related levels of analysis that "includes linguistic description of the language text, interpretation of the relationship between the (productive and interpretative) discursive processes and the text, and explanation of the relationship between the discursive processes and social processes". The following analysis will therefore target three dimensions and is conducted in three steps.

First, to analyze the texts as social events, their use of specific vocabulary related to risk and safety and the use of modality, was emphasized. The second step aims at relating the linguistic findings with social practices. To assess how the texts are mediated by social structures, an examination of their intertextuality will show how they are based and relate to one another (Fairclough, 1992, p. 102). It is the documents' constitutive intertextuality: how conventions are present in the texts without an explicit annunciation, which is given more weight in this analysis. Similarities within the texts represent what Fairclough (1992, p. 104) describes as interdiscursivity, or conventions represented in the different texts. Interdiscursivity is approached by analyzing: 1) how they overlap in their construction of RSM subjects; and 2) how specific areas of RSM are accentuated. 


\section{Porsanger}

Finally, as the third step, a discussion of the findings with social systems, of which the texts are part and through which they are explained (Fairclough, 2013, p. 74). The documents are therefore viewed as social events embedded in a system.

With this methodology, the analytical method is given priority in guiding the investigation, however, it is with a critical perspective that has an aim to reveal obscure power relationships. Hence, reliability in analysis is attempted by following the steps in Fairclough's (1992, 2013) CDA and being open about concepts and tools used in the analysis. In terms of validity, an objective reading of the texts is not possible as the author partakes in the constructions in a combination with the selected methodology. It enables and restricts what is illuminated and what is delineated from the analysis. Thus, the choice of perspective and theoretical lens, is not neutral but connected to the aim of the article and the author's background. Hence, it is not possible to clarify the intentions of the writers in an analysis of the selected documents (Skrede, 2017, p. 152). Moreover, it is not possible to establish any knowledge of how these texts influence teachers' convictions and practices. However, by shedding light on hegemonic discourses in the texts, the CDA opens a window to explore, and suggest, what might be taken for granted and come forward as neutral. Likewise, it may suggest possible unintentional consequences of discourses in the texts (Skrede, 2017, p. 155).

\section{Selection of documents}

This analysis is conducted on five regulative documents governing primary and secondary schools in Norway. Due to a national curriculum renewal effective from August 2020, two curricula for PE were analyzed. The selected documents for analysis are: 1) the Education Act (1998); 2) the Regulations Pursuant to the Education Act (2006); 3) the current Curriculum for Physical Education (KRO1-04) (Udir, 2015b); 4) the forthcoming Curriculum for Physical Education (KRO01-05) (Udir, 2019); and 5) the circular Proper Swimming and Rescue Training in Primary and Lower Secondary Education Udir-1-2008 (Udir, 2015a; my translation). Hereafter, these will be named for brevity: 1) the Act; 2) the Regulation; 3) the current Curriculum; 4) the forthcoming Curriculum; and 5) the Circular.

Albeit, the texts have different warrants and functions, their primarily govern Norwegian education and have an authoritative status in the field. The Ministry of Education and Research (2016), presents the Act (1998) and the Regulation (2006) as key legal texts that give students a statutory right of a safe learning environment. The mandate for both (curriculums/curricula) is to provide learning goals and warrants to the PE program, and is part of a National Curriculum for primary and secondary education and training. Due to their status as regulations, they draw on both pedagogical and legal warrants. Thus, what is stated in the curriculums is legally binding for teachers' compliance. As the only text in this article that is not established as a legal document, the Circular is an interpretation of selected paragraphs in the Act (1998) and the Regulation (2006) and give direction to teachers and schools. It was 
selected as it is the single regulative text that target a specific physical activity in the PE program and is a new representation in the field from 2008.

After reading the documents for an overview and to gain an impression of the content, sections from the documents, selected according to relevance to the research question, were pulled for the remaining analysis following the steps of the CDA. A general description of the analyzed texts is in Table 1.

Table 1. Description of the documents.

\begin{tabular}{|c|c|}
\hline Document & Description \\
\hline Act & $\begin{array}{l}\text { Effective from } 1998 \text {. Replaced older version from } 1986 . \text { Several older versions and } \\
\text { eldest from } 1969 . \text { In total, } 44 \text { pages. Structured in chapters by paragraphs. Analysis } \\
\text { limited to the general paragraph about students' school environment. }\end{array}$ \\
\hline Regulation & $\begin{array}{l}\text { Effective from } 2006 \text {. Replaced older version from 1999. In total, } 88 \text { pages. } \\
\text { Structured in chapters by paragraphs from the Education Act. The Regulation is a } \\
\text { more detailed explanation of the meaning of the text in the Education Act. Analysis } \\
\text { limited to chapter } 12 \text {, letters a, b, c, d, which concerns "[s]afety for students". }\end{array}$ \\
\hline $\begin{array}{l}\text { Current } \\
\text { Curriculum }\end{array}$ & $\begin{array}{l}\text { Effective from } 2015 \text {. Replaced older version from } 2012 \text {. Structured in chapters by } \\
\text { headings. Analysis limited to text aiming at primary and lower secondary education, } \\
\text { which is } 9 \text { pages long. }\end{array}$ \\
\hline $\begin{array}{l}\text { Forthcoming } \\
\text { Curriculum }\end{array}$ & $\begin{array}{l}\text { Effective from August } 2020 \text {. Will replace current version from } 2015 \text {. Structured in } \\
\text { chapters by headings. Analysis limited to text aiming at primary and lower secondary } \\
\text { education, which is } 8 \text { pages long. }\end{array}$ \\
\hline Circular & $\begin{array}{l}\text { Effective and new from } 2008 \text {. New version in } 2015 \text {. Structured in chapters by } \\
\text { number. Analyzed in full and consists of } 6 \text { pages. }\end{array}$ \\
\hline
\end{tabular}

The texts were read in Norwegian, which the author translated into English. An official translated English version of the current Curriculum supported the author with the translation of the curricula (Udir, 2015c).

\section{Analysis and findings}

\section{Linguistic description of the documents as social events Modality to command}

An analysis of modality was chosen because it offers important information regarding the message of the texts (Fairclough, 2013, p. 248). As mentioned, the Act (1998) put forward a statutory right in paragraph 9, letter A-2 stating that "[a]11 pupils attending primary and secondary schools are entitled to a good physical and psychosocial environment conducive to health, well-being and learning". This right is further elaborated in the Regulation (2006), paragraph 12, together with the increased use of modality concerning students' safety. The Circular, addressing water activities only, modality is used to describe how RSM shall or must carried out, demonstrated by a student-teacher ratio and in important areas of knowledge, such as alarm plans 


\section{Porsanger}

(Udir, 2015a). Albeit, schools have the right to "assess what is proper practice" (Udir, 2015 a, p. 1), their freedom of choice is wrapped by modal verbs. The combination of modality, connected to specific ways of doing RSM, might be interpreted as the only correct way in water activities. Teachers also seem to be a factor in RSM, as they are called out and "should ... pass a practical swimming test" (Udir, 2015a, p. 4). In the curriculums, modality is mostly used in relation to competence requirements and that students shall learn how to "move [...] about safely" in the current Curriculum (Udir, 2015b, p. 5) and "consider safety in outdoor activities" in the forthcoming Curriculum (Udir, 2019, p. 7).

\section{Vocabulary constructing risk and safety management}

It is expected that the use of words in these texts is to communicate a specific message and is therefore an element in the analysis. Considering the contemporary focus on risk, the risk concept appears in the Regulation (2006), and the Circular also brings up "risk for accidents" (Udir, 2015a, p. 1). The risk concept is not repeated to any extent in the other texts and might be a sign that the idea of risk, is not prevalent. However, safety is brought up recurrently, incorporated in the general right in the Act (1998) to activity-related safety concerns and competence aims in the curriculums. It may be that the risk discourse is in a process of recontextualizing, or coming forward, as a safety discourse within this field (Fairclough, 2013, p. 76). Thus, the reasons or ideology behind the emphasis on risk or safety might be the same, but they come forward as separate ideas, and are modified to the environment they are implemented.

In the current Curriculum, a pedagogical discourse where challenge and courage is promoted such as in the purpose: "[t]he subject shall provide pupils with physical challenges and the courage to test their own limits during spontaneous and organized activities" (Udir, 2015b, p. 1). Thus, students must be provided with such opportunities, which might entail the risk of injury if absolute safety is not applied. This seems to contrast with the Circular, that claims that "the risk of accidents occurring should be as little as possible," (Udir, 2015a, p. 1). Thus, these texts might be drawing on different discourses. If the safety discourse were to replace or encompass the pedagogical discourse it might create a safety logic where safety concerns trump other considerations. However, it is uncertain whether the forthcoming Curriculum (Udir, 2019) has any signs of such a development. It seems to put less emphasis on activityrelated challenges while promoting courage to promote personal and physical ability. For example, when Udir states in the core values that "[t]he subject shall also challenge their courage to test their own limits" (Udir, 2019, p. 2), it seems related to teachers' assessment of students' effort to challenge their physical capacity (Udir, 2019, p. 8) and movements (Udir, 2019, p. 5).

A prominent word that constructs RSM in the texts, is proper. In continuation of the general right in the Act (1998), the Regulation (2006) also includes proper as a foundation to define all RSM in PE; however, none of the curriculums comment on what proper refers to. This is similar to other concepts such as risk and accidents. 
Thus, the interpretation and implementation of risk, accident and proper, is left to schools and teachers, as they are not defined nor clarified. This entails a space for discretion, but also uncertainty, as it does not give any clear guidance as to how to apply the term in practice. On the other hand, this policy does not apply for water activities, where proper is elaborated upon in detail in the Circular and entails "issues of safety related to swimming, rescue training and bathing, and what the school owner should do to make this proper" (Udir, 2015a, p. 1).

The Circular also creates a dilemma, stating that "it is the schools which must consider ... what is proper practice" in water activities (Udir, 2015a, p. 1). This message is followed by a prospective "threat" when Udir emphasizes "... it will be a decisive point in an eventual compensation case following an accident, whether the student has been properly secured and whether the existing regulations have been followed" (Udir, 2015a, p. 1). Noted, the statement includes the legal sanctions in the proper discourse and might be an attempt to put more power behind their recommendations.

Considering the findings from the linguistic analysis, it is necessary to look at the discursive practices that mediate the use of language in the documents and the social structures.

\section{Intertextuality as a social and mediating practice}

\section{External intertextuality of the texts}

The Act (1998), Regulation (2006) and Circular (Udir, 2015a), have a clear external manifested intertextuality. The Circular (Udir, 2015a) mentions its relation to the Act (1998) and the current Curriculum (Udir, 2015b). The Regulation (2006) mentions the Act (1998) and references a further detailed explanation in the Circular (Udir, 2015a). A high degree of intertextuality is often a sign of a field that is changing (Skrede, 2017) and social change is often expressed in changes of discursive practices (Fairclough, 1992, p. 8). Because water activities are warranted in the PE curriculums with distinct competence goals, the Circular (Udir, 2015a) may function to bridge the regulative discourse with the pedagogical discourse. Thus, the entry of the Circular (Udir, 2015a) may bring about changes in the discursive order of the field. Noteworthy, none of the curricula clearly state any connection to the other three texts.

\section{Internal textuality in subjects of risk and safety management}

There is a general lack of teachers as RSM subjects and it is an indication in to how the texts position teachers. The Act (1998) targets school owners and school management as well as students whom are also defined as having the right to take part in the planning and implementation of their own safety. The Regulation (2006) presents and the Circular (Udir, 2015a) addresses the responsible supervisor as a prominent actor, and not teachers. Further, several new subjects enter the discourse in the Circular, such as the teacher/instructor and the assistant (Udir, 2015a, p. 3). 


\section{Porsanger}

When teachers are mentioned in the Circular, they are constructed in an alternate position to instructors, such as when they state that "the responsible teacher/instructor must be a good swimmer" (Udir, 2015a, p. 4). The choice to omit the teacher seems even more remarkable, if the alternative were to position the teacher as the only responsible subject in the text. On the other hand, the Circular states that "there shall be at least one teacher present during swimming lessons" (Udir, 2015a, p. 3). This teacher seems to be compelled in the obligatory swimming lessons to meet the requirements of pedagogical competence.

The controller in the role of an examiner is a new subject entering the discourse in the Circular (Udir, 2015a, p. 5). They are the subjects now positioned to, and responsible for, auditing and controlling teachers' water competence annually through a practical swimming and lifesaving test. The relationship between those subjects is also characterized by use of modality connected to the test. The subject, the controller, and the practice of examining teachers represent new features in Norwegian PE, making teachers subordinate actors to a testing regime.

\section{Internal textuality in areas of risk and safety management}

The Act (1998) requires safety throughout all of education, without specifically targeting any program or activity. In the Regulation (2006), selected areas are highlighted, such as water activities, traffic, and bicycling. In the Circular, (Udir, 2015a) water activities are the main area of concern and clearly stated. In addition to these areas, the current Curriculum at all year levels, 4, 7 and 10, also incorporate a safety discourse with regards to outdoor education in PE because the main topic "covers competence and skills needed to do things safely in nature" (Udir, 2015b, p. 2) and students shall learn to be "outdoors in a safe and functional manner" (Udir, 2015b, p. 4). In the forthcoming Curriculum, safety concerns are connected to outdoor travel, traffic, and water. For example, in the level 2 year, students shall practice "safe travels in traffic ... and by water" (Udir, 2019, p. 5). Due to the supposed versatility of the subject it seems plausible that the safety discourse has colonized some specific areas and is most prominent in water activities.

Having presented results from the linguistic analysis and intertextuality as social and mediating practice, the discussion will create a synthesis of the findings with social theory, as an answer to the third level of CDA.

\section{Discussion}

An emerging regulative discourse of teachers' risk and safety management

Looking at international PE policy, it seems plausible that accidents would impose more regulation. This practice seems legitimate if it was shown to be an effective method in preventing or reducing student injuries. However, there are indications that regulation is not implemented because it has shown itself effectual. Noted, the promotion of risk management has been related to neoliberal discourses internationally 
(Evans, 2014). As a possible alternative explanation to policy change due to safety, the CDA suggests that the Circular (Udir, 2015a) is a result of a dominant ideology of control. Consequently, regulative texts may be used to promote increased acceptance for audits, centralized power and more regulation of teachers' discretional space.

Thus, what is unformulated might be a sign of doxa in a field. If the regulative discourse with its directive standards becomes doxa, there is a general and significant acceptance of it that becomes common sense. More regulation may be interpreted as a natural practice and seem impossible to challenge. Those who internalize doxa will experience it as neutral and natural and position themselves thereafter.

Considering these five texts, the Circular (Udir, 2015a) seems to stand out positioned to promote change to RSM in water activities. On the other hand, if the policy and its degree of detail only applies to this activity, it would seem to imply a large space for contesting RSM discourses and heterodoxy in PE. Again, heterodoxy might support strong discretion among teachers.

\section{Regulation and teachers' discretional space}

In most cases, acts do not specifically and in detail instruct teachers and schools on how to execute or implement regulations. One possible reading of these texts is that RSM in PE is left open for discretion and is part of the doughnut hole available for teachers to assess. On the other hand, controls are enhanced as a measure that will restrict the perceived space for professional discretion. When Udir (2015a) writes in the Circular that practices might be assessed in judicial trials, it seems that they are forwarding this indirect "threat", to put pressure on schools to comply with their directives. This gives a rather remarkable and limited expression of teachers' choice. Following this argument, it is uncertain whether prospective controls and reminders of their external accountability will have the same effect. Most importantly, the threat seems to be a question of reducing the perceived and operated discretional space and not the actual space, since they are not legally obliged to follow the central recommendations. If teachers read the Circular (Udir, 2015a) as part of what Dworkin (1978) describes as the restriction belt or a part of the doughnut hole is not clear. As even when teachers exercise strong discretion, retrospective audits and emphasis on controls might give them the impression that they must make judgements based on weak discretion. As an example, viewing the term proper as a dichotomy, everything outside the dominant definition of proper might be read or interpreted as improper. The discourse representing proper RSM will therefore describe best practices in the field. The regulative discourse may therefore contribute to changing teachers' apprehension of discretional space, limit the use of the space available, or both. This is because when teachers use their discretion to apply Circular (Udir, 2015a) guidelines in water activities, it is in accordance with weak discretion (Dworkin, 1978).

Because the curriculums are characterized by a pedagogical discourse, it might put pressure on teachers as to which discourse to comply with. It would seem natural that teachers with a heterodox position, would choose not to take the swimming test 


\section{Porsanger}

or follow all of the recommendations. On the other hand, if teachers are not ideologically convinced of the Circular's (Udir, 2015a) methods, the texts may give the impression that have no alternatives due to the character of the regulative discourse.

\section{The (un)intentional devaluation of physical education teachers}

The constructions of RSM, and especially in water activities, might create new identities and positions within the field (Bourdieu, 1995; Fairclough, 1992, p. 65). Because, intentionally or not, a new actor in water activities is constructed in using the word, supervisor. It is unclear why teachers are not the main actors, as traditionally they have been responsible for teaching all aspects of PE, including water activities. Noteworthy, outsourcing seems common in PE internationally (Williams \& Macdonald, 2015). Such changes may influence the relationships and relative positions of teachers in PE. Thus, putting them in a subordinate position to a controller, and within a testing regime, is a remarkable step and seems to imply new policy in Norway. Thus, the controller is an extension of the ideology that requires teachers to do an annual examination. If this holds ground, it might incur social change and alterations to positions in Norwegian PE.

In this argument also lies the versatility of tools or alternative measures. Consider two other possible approaches: a reminder could have been forwarded, similarly, they could have mandated courses for teachers to stay current; alternatively, implicitly trust teachers and schools to assess whether they need training and/or what kind.

In terms of consequences for teachers, it is only possible to suggest how the Circular (Udir, 2015a) policy may influence teachers' practice. However, due to the legitimized power of these texts, teachers might be compelled to integrate the test of water competence in their professional position, with a disposition to be ready for inspection. This would be a developmental trait in the Norwegian field that emphasizes the need for critical examination and attention.

Teachers' weak positions might also stem from a lack of legitimation, which has led to the loss of jurisdiction (Abbott, 1988). If schools and teachers' capacity and competence to apply responsible RSM measures in PE and especially water activities are questioned, policies that reduce teachers' jurisdiction and discretional space, might be implemented.

\section{Conclusion}

The CDA of how teachers' RSM is constructed in five regulative documents reveals an emerging regulative discourse, albeit in selected areas of PE. The article suggests, that the discourse found in and through the Circular (Udir, 2015a), promotes central control of water activities and teachers' competence. The use of language in the texts, promotes obligation and gives an impression of neutrality. The CDA indicates that PE teachers are constructed in a weak position in relation to RSM. What seems to be teachers' loss of jurisdiction in water activities might come from a lack of trust in 
teachers' and schools' ability to conduct proper RSM. On the other hand, this might be enforced due to a dominant ideology.

However, more research is needed to examine juridification and regulative texts targeting PE to gain further insight into their construction. Likewise, how these constructions influence teachers' RSM practices is also highly relevant for further research.

\section{Author biography}

Lise Porsanger is a $\mathrm{Ph}$. D. candidate in Educational Sciences and Assistant Professor in Physical Education at the Department of Teacher Education at the Norwegian University of Science and Technology.

\section{Declaration of interest statement}

The author reports no conflict of interest.

\section{References}

Abbott, A. (1988). The system of professions: An essay on the division of expert labor. Chicago: University of Chicago Press.

Association for Physical Education. (2016). Safe practice in physical education, School Sport E Physical Activity. Retrieved from http://www.afpe.org.uk/physical-education/safe-practice-in-physical-education-schoolsport-physical-activity-2016/

Aven, T. M. \& van Kessenich, A. (2019). Teaching children and youths about risk and risk analysis: What are the goals and the risk analytical foundation? Fournal of Risk Research, 1-14.

Ball, S. J. 2017. The Education Debate. Bristol, Chicago: Policy Press.

Ball-King, L., Watt, J. \& Ball, D. (2012). The Rise and Fall of a Regulator: Adventure Sports in the United Kingdom. Risk Analysis, 33(1), 15-23.

Barwood, D. (2018). Outdoor education policy update. Retrieved from https://www.achperwa.org.au/outdooreducation-policy-update/

Benes, S. S. (2013). Safety in physical education. In A. C., Cory, D. C., Wiley \& Centers for Disease Control and Prevention (U.S.) (Eds.), Encyclopedia of School Health, (pp. 519-521). Los Angeles: SAGE Publications.

Boote, D. N. (2006). Teachers' professional discretion and the curricula. Teachers and Teaching: Theory and Practice, 12(4), 461-78.

Bourdieu, P. (1990). The Logic of Practice. Stanford: Stanford University Press.

Bourdieu, P. (1995). Distinksjonen: En sosiologisk kritikk av dømmekraften. Oslo: Pax.

Bowen, G. A. (2009). Document analysis as a qualitative research method. Qualitative Research fournal, 9(2), 27-40.

Connolly, M. \& Haughton, C. (2015). The perception, management and performance of risk amongst Forest School educators, British fournal of Sociology of Education, 38(2), 105-124.

Dahl, L., Standal, Ø. \& Moe, V. (2018). Norwegian teachers' safety strategies for Friluftsliv excursions: Implications for inclusive education, Fournal of Adventure Education and Outdoor Learning, 19(3), 256-268.

Dallat, C., Salmon, P. M., \& Goode, N. (2015). All about the teacher, the rain and the backpack: The lack of a systems approach to risk assessment in school outdoor education programs. Procedia Manufacturing, 3, 1157-1164.

Dewey, J. (2008). Democracy and education: An introduction to the philosophy of education. Champaign, Ill.: [Book Jungle]. (Original work published 1916).

Dworkin, R. (1978). Taking rights seriously. London: Duckworth. 


\section{Porsanger}

Education Act. (1998). Lov om grunnskolen og den vidaregåande oppleringa [The Education Act]. Retrieved from https:/lovdata.no/dokument/NL/lov/1998-07-17-61

Evans, J. (2014). Neoliberalism and the future for a socio-educative physical education. Physical Education and Sport Pedagogy, 19(5), 545-558.

Fairclough, N. (1992). Discourse and social change. Cambridge: Polity Press.

Fairclough, N. (2013). Critical discourse analysis: The critical study of language. New York: Taylor \& Francis.

Fischhoff, B., Slovic, P., Lichtenstein, S., Read, S. \& Combs, B. (1978). How safe is safe enough? A psychometric study of attitudes towards technological risks and benefits. Policy Sciences, 9(2), 127-152.

Freidson, E. (2001). Professionalism: The third logic. Cambridge: Polity Press.

Giddens, A. (1999). Risk and responsibility. Modern Law Review, 62(1), 1-10.

Habermas, J. (1987). The theory of communicative action: $2:$ Lifeworld and system :A critique of functionalist reason (Vol. 2). Boston: Beacon Press.

Health and Safety Executive. (2011). School trips and outdoor learning activities: Tackling the health and safety myths. Retrieved from http://www.hse.gov.uk/services/education/school-trips.pdf

Magnussen, A. M. \& Nilssen, E. (2013). Juridification and the construction of social citizenship. Fournal of Law and Society, 40(2), 228-248.

Maurice, P., Lavoie, M., Laflamme, L., Svanström, L., Romer, C. \& Anderson, R. (2001). Safety and safety promotion: Definitions for operational developments. Injury Control and Safety Promotion, 8(4), 237-240.

Ministry of Education and Research. (2016). Laws and regulations governing schools. Retrieved from https:// www.regjeringen.no/en/topics/education/school/artikler/regelverk-for-skolen/id2353805/?expand=factbox 2511932

Molander, A., Grimen, H., \& Eriksen, E. O. (2012). Professional discretion and accountability in the welfare state. Fournal of Applied Philosophy, 29(3), 214-230.

Murphy, K. L., \& Beh, H. B. (2014). The standard of care and the assumption of risk defense in a negligent injury case in a physical education class. Fournal of Physical Education, Recreation and Dance, 85(8), 41-43.

Norwegian Directorate for Education and Training. (2015a). Forsvarlig svømme- og livredningsopplaring $i$ grunnskoleopplceringen Udir-1-2008 [Proper swimming- and rescue training in primary and lower secondary education Udir-1-2008]. Retrieved from https://www.udir.no/regelverkstolkninger/opplaring/Innhold-i-opplaringen/ Udir-1-2008-Forsvarlig-svomme--og-livredningsopplaring-i-grunnskoleopplaringen/

Norwegian Directorate for Education and Training. (2015b). Lareplan i kroppsøving (KRO1-04) [Curriculum for physical education (KRO1-04)]. Retrieved from https://www.udir.no/k106/KRO1-04

Norwegian Directorate for Education and Training. (2015c). Curriculum for physical education (KRO1-04). Retrieved from https://www.udir.no/kl06/KRO1-04?lplang=http://data.udir.no/k106/eng

Norwegian Directorate for Education and Training. (2019). Lereplan i kroppsøving (KRO01-05) [Curriculum for physical education (KRO01-05). Retrieved from https://www.udir.no/lk20/kro01-05

Norwegian Directorate of Health. (2019). Personskadedata 2018 [Personal injury data 2018]. Retrieved from https:/www.helsedirektoratet.no/rapporter/personskadedata-arsrapporter/Årsrapport\%20personskadedata\%202018.pdf/_attachment/inline/47be1c03-58f1-42e4-b54f-ff4b4a164a7b:ed678317124dbb725fb6016b9cc5b3e0b1d6aa77/Årsrapport\%20personskadedata\%202018.pdf

NOU 2003:19. (2003). Makt og demokrati: Sluttrapport fra makt- og demokratiutredningen. Retrieved from https:/www.regjeringen.no/no/dokumenter/nou-2003-019/id118893/?ch=1

Park, Y. (2018). How do specialist teachers practice safety lessons? Exploring the aspects of physical education safety lessons in elementary schools. International Electronic fournal of Elementary Education, 10(4), 457-461.

Power, M. (1997). The audit society: Rituals of verification. Oxford: Oxford University Press.

Power, M. (2004). The risk management of everything. The fournal of Risk Finance, 5(3), 58-65.

Regulations Pursuant to the Education Act. (2006). Forskrift til opplceringslova [The regulations pursuant to the Education Act] (FOR-2006-06-23-724). Retrieved from https://lovdata.no/dokument/SF/forskrift/200606-23-724?q=forskrift til opplæringsloven

Rothe, P. J. (2009). The voluntary use of physical education safety guidelines in schools. Fournal of Physical Education, Recreation E Dance, 80(3), 43-49.

Rothstein, H. (2006). The institutional origins of risk: A new agenda for risk research. Health, Risk E Society, $8(3), 215-221$.

Rothstein, H., Huber, M. \& Gaskell, G. (2006). A theory of risk colonization: The spiraling regulatory logics of societal and institutional risk. Economy and Society, 35(1), 91-112. 


\section{The reconstruction of physical education teachers}

Russell, L. D. \& Babrow, A. S. (2011). Risk in the making: Narrative, problematic integration, and the social construction of risk. Communication Theory, 21(3), 239-260.

Sawyer, T. H. (2011a). Is simple negligence enough to prevail? Fournal of Physical Education, Recreation $\mathcal{E}$ Dance, $82(5), 8-12$.

Sawyer, T. H. (2011b). Supervision: A key to safe physical education classes. Fournal of Physical Education, Recreation $\mathcal{E}$ Dance, 82(6), 9-11.

Schmidt, V. A. (2008). Discursive institutionalism: The explanatory power of ideas and discourse. Annual Review of Political Science, 11(1), 303-326.

Schuller, A. A. \& Kopjar, B. (2000). Skader oppstått på skolen hos barn mellom sju og 15 år. Tidsskrift for Den Norske Legeforening, 120(3), 301-305.

Severs, J., Whitlam, P., \& Woodhouse, J. (2003). Safety and risk in primary school physical education: A guide for teachers. London: Routledge.

Skrede, J. (2017). Kritisk diskursanalyse. Oslo: Cappelen Damm Akademisk.

Taylor, S. (2004). Researching educational policy and change in 'new times': Using critical discourse analysis. fournal of Education Policy, 19(4), 433-451.

Williams, B. J., \& Macdonald, D. (2015). Explaining outsourcing in health, sport and physical education. Sport, Education and Society, 20(1), 57-72.

Young, D. C. (2007). Physical education, tort law and risk avoidance. Education E Law fournal, 17(2), $223-243$. 